\title{
PENGARUH KECERDASAN EMOSIONAL TERHADAP PRESTASI BELAJAR PENDIDIKAN PANCASILA DAN KEWARGANEGARAAN SISWA SMA NEGERI 5 YOGYAKARTA
}

\author{
Heri Kurnia $^{1}$ dan Joko Wahono ${ }^{2}$ \\ ${ }^{1,2}$ Pendidikan Pancasila dan Kewarganegaraan, Universitas Cokroaminoto Yogyakarta \\ Jl. Perintis Kemerdekaan, Gambiran, Pandeyan, Umbulharjo, Kota Yogyakarta 55161 \\ ${ }^{1}$ Email: herikurnia@ucy.ac.id \\ ${ }^{2}$ Email: jokowahono@ucy.ac.id
}

\begin{abstract}
ABSTRAK
Penelitian ini bertujuan untuk mengetahui pengaruh kecerdasan emosional terhadap prestasi belajar pendidikan pancasila dan kewarganegaraan siswa SMA Negeri 5 Yogyakarta tahun ajaran 2019/ 2020. Penelitian ini merupakan penelitian deskriptif kuantitatif, data yang dikumpulkan berupa data kuantitatif (prestasi belajar PPKn atau nilai rapor) dan data kalitatif yang dikuantifikasi (kecerdasan emosional), penelitian ini dilakukan di SMA Negeri 5 Yogykarta pada bulan Maret 2020.

Jumlah sampel pada penelitian ini sebanyak 720 responden, dengan rincian kelas $\mathrm{X}$ ada 8 kelas, kelas XI ada 8 kelas dan kelas XII ada 8 kelas, jadi jumlah total ada 24 kelas. Dari 24 kelas tersebut (dari masing-masing kelas) diambil sampel sebanyak 30 siswa dengan teknik simple random sampling. Data diperoleh dari kuesioner kemudian diolah dengan teknik analisis regresi sederhana dan analisis koefisien determinasi $\left(\mathrm{R}^{2}\right)$.

Untuk data kecerdasan emonional $(\mathrm{X})$ peneliti mengambil data dengan menyebarkan kuesioner, sedangkan nilai prestasi belajar Pendidikan Pancasila dan Kewarganegaraan (PPKn) siswa (Y) merupakan nilai akhir (rapor) pada semester genap tahun ajaran 2019/ 2020.

Hasil penelitian menunjukkan: analisis statistik menghasilkan persamaan regresi $\mathrm{Y}=74,298+$ $0,165 \mathrm{X}$, artinya jika nilai kecerdasan emosional $(\mathrm{X})$ meningkat 1 satuan maka nilai prestasi belajar PPKn (Y) akan meningkat sebesar 0,165 satuan dengan nilai konstanta 74.298. Pengujian hipotesis menunjukkan bahwa variabel independen kecerdasan emosional terbukti secara signifikan mempengaruhi dependen prestasi belajar PPKn. Koefisien determinasi $\left(\mathrm{R}^{2}\right)$ yang diperoleh adalah 0,59 (5,9\%), artinya variabel kecerdasan emosional memiliki pengaruh kontribusi sebesar 5,9\% terhadap variabel prestasi belajar PPKn dan 94,1\% lainnya dipengaruhi oleh faktor-faktor lain di luar variabel kecerdasan emosional.
\end{abstract}

Kata Kunci: Kecerdasan Emosional, Prestasi belajar PPKn, SMA Negeri 5 Yogyakarta

\begin{abstract}
This study aims to determine the effect of emotional intelligence on the learning achievement of Pancasila education and citizenship of students at SMA Negeri 5 Yogyakarta in the 2019/2020 academic year. This research is a quantitative descriptive study, the data collected is in the form of quantitative data (PPKn learning achievement or report cards) and data qualitative quantified (emotional intelligence), this research was conducted at SMA Negeri 5 Yogykarta in March 2020. Number of samples in this study were 720 respondents, with details of class $X$ having 8 classes, class XI there are 8 classes and class XII there are 8 classes, so there are a total of 24 classes. Of the 24 classes (from each class) a sample of 30 students was taken using simple random sampling technique. Data obtained from questionnaires are then processed by a simple regression analysis and coefficient of determination $\left(R^{2}\right)$.

For the data on emotional intelligence $(X)$, the researchers took the data by distributing questionnaires, while the students' learning achievement scores for Pancasila and Citizenship Education (Y) were the final grades (report cards) in the even semester of the 2019/2020 school year.

The results showed: statistical analysis. produces a regression equation $Y=74.298+0.165 X$,
\end{abstract}


meaning that if the value of emotional intelligence $(X)$ increases by 1 unit, the learning achievement value of PPKn (Y) will increase by 0.165 units with a constant value of 74,298. Hypothesis testing shows that the independent variable emotional intelligence is proven to significantly affect the dependent learning achievement of PPKn. The coefficient of determination $\left(R^{2)}\right.$ obtained was $0.59(5.9 \%)$, meaning that the variable has an influence emotional intelligence contributes 5.9\% to the achievement variable learn PPKn and $94.1 \%$ are influenced by other factors outside emotional intelligence variable.

Keywords: Emotional Intelligence, PPKn learning achievement, SMA Negeri 5 Yogyakarta

\section{PENDAHULUAN}

Dengan berkembangnya teknologi seperti komputer dan internet sangat memudahkan siswa untuk mengembangkan ilmu pengetahuan. Walaupun demikian, teknologi yang semakin berkembang dan pesat tersebut belum dapat dijadikan jaminan bagi dunia pendidikan untuk mencapai hasil yang maksimal. Seperti yang sudah kita ketahui bersama, bahwa undang-undang nomor 20 Tahun 2003 tentang Sistem Pendidikan Nasional (SISDIKNAS) Pasal 3 menjelaskan bahwa "Pendidikan nasional berfungsi mengembangkan kemampuan dan membentuk watak serta peradaban bangsa yang bermartabat dalam rangka mencerdaskan kehidupan bangsa, bertujuan untuk berkembangnya potensi peserta didik agar menjadi manusia yang beriman dan bertaqwa kepada Tuhan Yang Maha Esa, berakhlak mulia, sehat, berilmu, cakap, kreatif, mandiri dan menjadi warga Negara yang demokratis serta bertanggungjawab.

Salah satu faktor yang dapat mendukung keberhasilan proses pembelajaran disetiap sekolah adalah sikap dan mental dari siswa itu sendiri yang disebut dengan kecerdasan emosional $(E Q)$, dengan adanya kecerdasan emosional siswa dituntut untuk bisa mengendalikan emosinya dalam segala hal, terutama dalam menghargai diri sendiri, mengetahui kekuatan diri sendiri, berpikir sebelum bertindak, merasakan suasana hati dan lain sebagainya.

Pentingnya kecerdasan emosional, dibuktikan dengan hasil penelitian jangka panjang terhadap 95 siswa Hardvard lulusan tahun 1940-an. Puluhan tahun kemudian, mereka yang saat kuliah dulu mempunyai kecerdasan intelektual tinggi, namun egois dan pergaulannya kurang luas, ternyata hidupnya tidak terlalu sukses (berdasar gaji, produktivitas, serta status bidang pekerjaan), dibandingkan dengan orang yang kecerdasan intelektualnya biasa saja tetapi mempunyai banyak teman, pandai berkomunikasi, mempunyai empati, tidak temperamental sebagai manifestasi dari tingginya kecerdasan emosi, sosial dan spiritual (dalam Tesis Heri Kurnia, 2017) yang sudah dipublikasikan di Academy of Education Journal volume 10 nomor 01 (2019). 
Ironisnya masih banyak program pendidikan di Indonesia yang hanya berpusat pada kecerdasan akal (IQ) saja yaitu berorientasi untuk menghasilkan nilai akademik, padahal yang diperlukan sebenarnya adalah bagaimana mengembangkan kecerdasan hati seperti pengenalan diri, pengendalian diri dan motivasi. Banyak contoh di sekitar kita membuktikan bahwa orang yang memiliki kecerdasan intelektual saja tetapi tidak memiliki kecerdasan emosional, belum tentu sukses di dunia pekerjaan tetapi terpuruk di tengah persaingan. Sebaliknya banyak orang yang hanya berpendidikan formal lebih rendah ternyata banyak yang lebih berhasil karena diimbangi dengan kecerdasan emosional yang baik dan tinggi.

Melalui kecerdasan emosional, seorang siswa mampu untuk mengelola perasaannya, kemampuan untuk memotivasi dirinya, kesanggupan untuk tegar dalam menghadapi frustasi, kesanggupan mengendalikan dorongan dan menunda kepuasan sesaat, mengatur suasana hati yang reaktif, serta mampu berempati dan bekerja sama dengan orang lain. Kecerdasan ini yang mendukung seorang siswa dalam mencapai tujuan dan cita-citanya. Pembelajaran yang hanya berpusat pada kecerdasan intelektual tanpa menyeimbangkan sisi emosional akan menghasilkan generasi yang mudah putus asa, depresi, suka tawuran bahkan menggunakan obat-obat terlarang, sehingga banyak siswa yang kurang menyadari tugasnya sebagai seorang siswa akan mengakibatkan kurangnya motivasi untuk belajar dan sulit untuk berkonsentrasi, sehingga siswa akan sulit untuk memahami suatu mata pelajaran.

\section{METODE PENELITIAN}

Jenis penelitian ini adalah penelitian deskriptif, data yang dikumpulkan berupa data kuantitatif (dalam hal ini prestasi belajar PPKn) dan data kualitatif yang dikuantifikasi (dalam hal ini adalah kecerdasan emosional). Data nilai prestasi belajar PPKn diambil dari nilai rapor semester genap tahun ajaran 2019/2020, dan data kecerdasan emosional diambil dari hasil penyebaran angket.

Penelitian ini bertujuan untuk mencari pengaruh antara dua variabel yaitu variabel $\mathrm{X}$ (kecerdasan emosional) dan variabel Y (prestasi belajar PPKn). Pendekatan ini termasuk penelitian kuantitatif mengacu kepada pendapat Sukardi (2010:15) menyatakan, "Penelitian kuantitatif adalah data penelitian berupa angka-angka yang dianalisis menggunakan statistik".

Penelitian ini berlokasi di SMA Negeri 5 Yogyakarta, yang beralamat di Jl. Nyi Pembayun No.39, Prenggan, Kec. Kotagede, Kota Yogyakarta, Daerah Istimewa 
Yogyakarta 55172. Pelaksanaan penelitian dilaksanakan pada bulan Maret 2020. Populasi dalam penelitian ini adalah seluruh siswa SMA Negeri 5 Yogyakarta sebanyak 733 siswa, dapat dilihat pada tabel 1 di bawan ini:

Tabel 1 Populasi penelitain

\begin{tabular}{|c|c|c|}
\hline No & Uraian & Peserta Didik \\
\hline 1 & Laki-laki & 300 \\
2 & Perempuan & 473 \\
& Total & $\mathbf{7 7 3}$ \\
\hline
\end{tabular}

Sumber: Data ini peneliti akses dari website data pokok pendidikan dasar dan menengah (DAPODIKDASMEN).

Sedangkan sampel adalah bagian dari populasi yang dijadikan contoh dan diharapkan dapat mewakili populasi. Teknik pengambilan sampel yang dilakukan oleh peneliti adalah dengan teknik simple random sampling maka peneliti mengambil sampel dengan cara acak sederhana, dalam hal ini yang diacak secara sederhana adalah siswa yang dijadikan sampel penelitian. Dengan ketentuan dari setiap kelas yang dijadikan sampel sebanyak 30 siswa.

Teknik pengumpulan data dalam penelitian ini adalah menggunakan kuesioner dan dokumentasi, yakni: Pengambilan data kecerdasan emosinal menggunakan kuesioner (15 butir pernyataan). Dan pengambilan data prestasi belajar PPKn menggunakan dokumentasi (nilai ujian akhir atau rapor semester genap tahun ajaran 2019/2020).

Analisis data dalam penelitian ini menggunakan analisis deskriptif dan analisis inferensial. Analisis deskriptif digunakan untuk mengungkap variabel-variabel yang ada. Analisis inferensial digunakan untuk menguji hipotesis sebagai dasar pengambilan kesimpulan. Analisis data menggunakan bantuan aplikasi komputer program SPSS (Statistical Product and Service Solutions).

- Analisis deskriptif statistik

Untuk mempermudah memperoleh gambaran mengenai karakteristik dan jawaban responden, tegasnya data penelitian variabel independen yaitu $\mathrm{X}$ (kecerdasan emosional) dan variabel terikat Y (prestasi belajar PPKn). Dalam analisis deskripsi penelitian ini, dengan sengaja peneliti akan menampilan data antara lain: jumlah responden, skor terrendah, skor tertinggi, rata-rata (mean) dan standar deviasi.

- Analisis regresi sederhana

Alasan penggunaan analisis regresi sederhana karena dalam penelitian ini hanya 2 variabel, 1 variabel bebas dan 1 variabel terikat. Analisis regresi sederhana dalam penelitian ini dilakukan untuk mengetahui besarnya pengaruh kecerdasan emosional (X) terhadap prestasi belajar PPKn (Y). 
Kerangka pemikiran dalam peneliti adalah sebagai berikut:

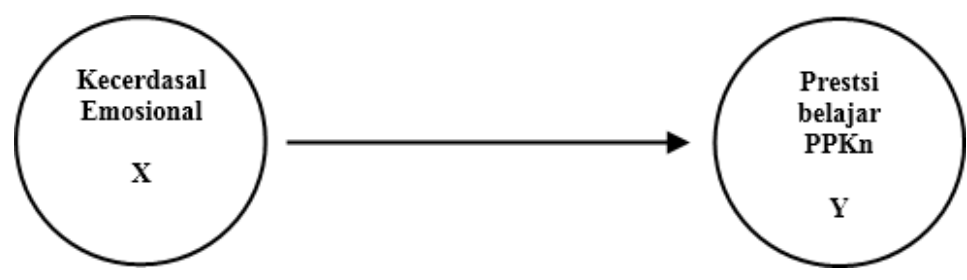

Gambar 1. Kerangka berpikir penelitian

Pengajuan hipotesis dalam peneliti adalah sebagai berikut:

Diduga kecerdasan emosional berpengaruh secara signifikan terhadap prestasi belajar Pendidikan Pancasila dan Kewarganegaraan siswa SMA Negeri 5 Yogyakarta tahun ajaran $2019 / 2020$.

\section{HASIL DAN PEMBAHASAN}

Sebelum melaksanakan penelitian, dengan sengaja peneliti merancang dan membuat instrument penelitian terlebih dahulu. Pelaksanaan pra penelitian dilaksanakan pada 3 sampai dengan 20 Februari 2020, tepatnya kelas X dilaksanakan pada tanggal 3, 5 dan 6 Februari 2020, kelas XI dilaksanakan pada 10, 12 dan 13 Februari 2020, dan kelas XII dilaksanakan pada tanggal 17, 19 dan 20 Februari 2020.

Selanjutnya, instrument penelitian adalah alat atau fasilitas yang digunakan oleh peneliti dalam mengumpulkan data. Jenis instrumen yang digunakan dalam penelitian ini adalah angket atau kuesioner yang berbentuk rating scale (skala bertingkat) dengan metode pengisian check-list.

Untuk memperoleh data kecerdasan emosional siswa, peneliti menyebarkan angket/ kuesioner, sebanyak 15 pernyataan. Sebelum instrumen penelitian digunakan kedalam penelitian yang riil atau nyata (penelitian yang sesungguhnya), maka dilakukan uji coba instrumen terlebih dahulu. Selanjutnya data dari hasil uji coba tersebut dapatlah diketahui kevalidan (validitas) dan kereliabilitasan (reliabelitas) dari instrumen tersebut.

Dalam penelitian ini indokator kecerdasan emosional terdiri atas 5 (lima) indikator, yaitu pengenalan diri (self awareness), pengendalian diri (self regulation), motivasi (motivation), empati (emphaty) dan keterampilan sosial (social skill). Berdasarkan definisi operasional dan indikator kecerdasan emosional di atas, maka disusun kisi-kisi angket seperti tertera pada tabel 2 berikut ini. 


\begin{tabular}{|c|c|c|c|}
\hline \multicolumn{4}{c}{ Tabel 2 kisi-kisi angket kecerdasan emosional } \\
\hline Variabel & Indikator & Jumlah Item & No Item \\
\hline & Pengenalan diri & 3 & $1,2,3$ \\
& Pengendalian diri & 3 & $4,5,6$ \\
Kecerdasan Emosional & Motivasi & 4 & $7,8,9,10$ \\
& Empati & 2 & 11,12 \\
& Keterampilan sosial & 3 & $13,14,15$ \\
& Jumlah item & $\mathbf{1 5}$ & \\
& &
\end{tabular}

Sumber: Rekapitulasi kisi-kisi angket kecerdasan emosional

Item variabel kecerdasan emosional diukur dengan menggunakan skala bertingkat. Pembobotan dalam angket variabel kecerdasan emosional digunakan skala bertingkat dengan 5 (lima) poin pernyataan pada skala. Sugoyono (2011: 93) mengatakan skala Likert digunakan untuk mengukur sikap, pendapat dan persepsi seseorang atau sekelompok orang tentang fenomena sosial. Jawaban setiap item instrumen mempunyai gradasi dari sangat positif sampai dengan sangat negatif yang kemudian diberi skor.

Pernyataan item dapat bersifat positif dan dapat pula bersifat negatif. Urutan penyataan positif beserta skornya adalah Sangat Setuju (SS), Setuju (S), Kurang Setuju (KS), Tidak Setuju (TS), Sangat Tidak Setuju (STS) $=5$, 4, 3, 2, 1. Selanjutnya urutan pernyataan negatif beserta skornya adalah Sangat Tidak Setuju (STS), Tidak Setuju (TS), Kurang Setuju (KS), Setuju (S), Sangat Setuju (SS) = 1, 2, 3, 4, 5. Instrumen penelitian dengan skala likert dapat dibuat dalam bentuk checklist ataupun pilihan ganda. Akan tetapi instrumen penelitian pada penelitian ini menggunakan skala likert dalam bentuk checklist.

a. Penyuntingan

Penyuntingan bertujuan untuk melakukan penyempurnaan instrumen angket. Kegiatan dalam penyuntingan ini bertujuan untuk membuat petunjuk pengisian angket, pernyataan-pernyataan yang sesuai dengan kisi-kisi dan koreksi penulisannya, serta akhirnya menggunakan instrumen tersebut.

b. Ujicoba Instrumen (Uji Kalibrasi)

Sebelum digunakan untuk penelitiaan yang riil/ nyata atau yang sesungguhnya di lapangan, maka instrumen angket kecerdasan emosional yang sudah tersusun dilakukan uji kalibrasi terlebih dahulu. Hal ini dimaksudkan agar dapat diketahui layak tidaknya angket tersebut digunakan. Kelayakan instrumen penelitian didasarkan pada dua persyaratan, yaitu validitas dan reliabilitas. Uji coba instrumen diterapkan kepada seluruh siswa kelas X, kelas XI dan kelas XII SMA Negeri 5 Yogyakarta pada semester genap tahun ajaran 2019/ 2020 yang berjumlah 720 siswa. Dalam hal ini pengambilan 
sempel dilakukan dengan ketentuan setiap kelas diambil sempel sebanyak 5 siswa, adalah sebagai berikut:

Tabel 3 data responden pra penelitian

\begin{tabular}{|c|c|c|}
\hline No & Kelas & Jumlah kelas \\
\hline 1 & X MIPA & 6 \\
2 & X IPS & 2 \\
3 & XI MIPA & 6 \\
4 & XI IPS & 2 \\
5 & XII MIPA & 6 \\
6 & XII IPS & 2 \\
& Total kelas & $\mathbf{2 4}$ \\
\hline
\end{tabular}

Sumber: data responden pra penelitian

Dari table 3 di atas, disimpulan bahwa kelas X sebanyak 8 kelas, kelas XI sebanyak 8 kelas dan kelas XII sebanyak 8 kelas jadi jumlah total ada 24 kelas di SMA Negeri 5 Yogyakarta. Selanjutnya dan dari setiap masing-masing kelas diambil sampel sebanyak 5 siswa, maka jumlah total 24 kelas X 5 siswa adalah sebanyak 120 siswa/ responden. Dari hasil uji coba tersebut kemudian dianalisis untuk mengetahui tingkat validitas dan reliabititas instrumen.

- Analisis validitas

Cara melakukan pengujian instrumen dengan menggunakan korelasi skor butir dengan skor total "Product Momement (Karl Pearson)". Analisis dilakukan dengan menggunakan bantuan komputer yaitu dengan menggunakan program SPSS Versi 23, dengan batas angak kritis 0,05. Kriteria pengujian membandingkan antara angka $r$ hitung dengan $r$ tabel. Jika $r$ hitung $>r$ tabel maka instrumen tersebut berarti valid, apabila sebaliknya jika $r$ hitung $<r$ tabel berarti instrumen tersebut dikatakan tidak valid dan tidak layak untuk dipergunakan sebagai alat bantu dalam melakuakn penelitian.

Penentuan banyaknya item didasarkan pada waktu yang telah disediakan oleh peneliti untuk menyelesaikan pengisian angket tersebut. Dengan asumsi setiap butir pernyataan dapat diselesaikan oleh responden dalam waktu 1 menit, maka seluruh item yang akan di checklist dapat terselesaikan dalam waktu 15 menit. Cadangan waktu yang disediakan oleh peneliti sebanyak 2 menit, maka untuk menyelesaikan seluruh pernyataan alokasi waktu yang dibutuhkan sebanyak 17 menit. Hasil uji coba dengan jumlah item kecerdasan emosional sebanyak 15 item, jumlah responden sebanyak 120 siswa, dan seluruh item (ke-15 item) pernyataan memenuhi kevalidan dengan taraf signifikansi sebesar 0,05 atau sama dengan 5\%. Hal ini diketahui dari mengkonsultasikan hasil analisis ke tabel harga kritik dari $r$ Product-Moment pada $\mathrm{N}=$ 
120 didapat koefisisensi korelasi $(r)$ tabel sebesar 0.176 . Item instrumen penelitian tergolong valid dapat dilihat ada tabel 4 berikut di bawah ini.

Tabel 4 Perbandingan $r$ hitung dengan $r$ tabel

Uji coba angket kecerdasan emosional

\begin{tabular}{|c|c|c|c|c|}
\hline \multicolumn{2}{|c|}{ Nomor } & \multirow{2}{*}{$r$ hitung } & $r$ tabel & \multirow{2}{*}{ Keterangan } \\
\hline Urut & Item & & 0.176 & Valid \\
2 & 1 & 0,479 & 0.176 & Valid \\
3 & 2 & 0,550 & 0.176 & Valid \\
4 & 3 & 0,703 & 0.176 & Valid \\
5 & 4 & 0,659 & 0.176 & Valid \\
6 & 5 & 0,803 & 0.176 & Valid \\
7 & 7 & 0,720 & 0.176 & Valid \\
8 & 8 & 0,798 & 0.176 & Valid \\
9 & 9 & 0,798 & 0.176 & Valid \\
10 & 10 & 0,845 & 0.176 & Valid \\
11 & 11 & 0,730 & 0.176 & Valid \\
12 & 12 & 0,704 & 0.176 & Valid \\
13 & 13 & 0,798 & 0.176 & Valid \\
14 & 14 & 0,816 & 0.176 & Valid \\
15 & 15 & 0,807 & 0.176 & Valid \\
\hline
\end{tabular}

Sumber: Rekapitulasi hasil hitung angket kecerdasan emosional

- Analisis reliabilitas

Taraf reliabilitas (keajegan) suatu instrumen atau suatu tes dinyatakan dalam bentuk koefisien reliabilitas. Besarnya koefiseien reliabilitas berkisar antara -1,00 sampai dengan 1,00. Semakin mendekati 0,00 berarti reliabilitasnya semakin rendah, demikian pula sebaliknya. Koefisien reliabilitas dengan angka negatif (-) sangat rendah. Agar memiliki gambaran yang jelas tentang hal tersebut maka dapat dilihat dalam tabel 5 berikut ini.

\section{Tabel 5 Koefisien korelasi dan kualifikasinya}

\begin{tabular}{|c|c|}
\hline Koefisien korelasi & Kualifikasi \\
\hline $0,91-1,00$ & Sangat tinggi \\
$0,71-0,90$ & Tinggi \\
$0,41-0,70$ & Cukup \\
$0,21-0,40$ & Rendah \\
Negatif $-0,20$ & Sangat rendah \\
\hline
\end{tabular}

Sumber: Ing. Masidjo (2006: 141)

Uji coba instrumen variabel kecerdasan emosional terhadap 120 responden setelah dianalisis dengan menggunakan bantuan komputer melalui program SPSS versi 23, dengan rumus Alpha Cronbach's diperoleh hasil koefisien reliabilitas sebesar 0,937. Angka tersebut jika mengacu kepada tabel 8 berikut di bawah ini, berarti memiliki 
tingkat reliabilitas tinggi. Oleh karena itu instrumen kecerdasan emosional memenuhi persyaratan atau reliabel untuk digunakan dalam penelitian, adalah sebagai berikut:

Tabel 6 Hasil olah data melalui SPSS

\begin{tabular}{|c|c|c|}
\hline Variabel & Cronbach's Alpha & Keterangan \\
\hline Kecerdasan Emosional (X) & 0,937 & Reliabel \\
\hline
\end{tabular}

Sumber: Hasil olah data primer pra penelitian

\section{Pelaksanaan Penelitian}

Penelitian ini bertempat di SMA Negeri 5 Yogyakarta, yang beralamat di Jl. Nyi Pembayun No.39, Prenggan, Kecamatan Kotagede, Kota Yogyakarta, Daerah Istimewa Yogyakarta Kode Pos 55172. Penelitian ini dilaksanakan pada bulan Maret 2020, tepatnya untuk kelas X dilaksanakan pada tanggal 2, 4 dan 5 Maret 2020, untuk kelas XI dilaksanakan pada tanggal 9, 11 dan 12 Maret 2020 dan untuk kelas XII dilaksanakan pada16, 18 dan 19 Maret 2020, serta tahap akhir pelaksanaan penelitian untuk kelas X, XI dan XII dilaksanakan pada tanggal 23, 25 dan 26 Maret 2020.

Jumlah responden pada penelitian ini sebanyak 720 responden, dengan rincian kelas $\mathrm{X}$ ada 8 kelas, kelas XI ada 8 kelas dan kelas XII ada 8 kelas, jadi jumlah total ada 24 kelas. Dari 24 kelas tersebut, dari masing-masing kelas diambil sampel sebanyak 30 siswa. Untuk data kecerdasan emonional (X) peneliti mengambil data dengan menyebarkan kuesioner, sedangkan nilai prestasi belajar Pendidikan Pancasila dan Kewarganegaraan/ PPKn siswa (Y) merupakan nilai akhir pada semester genap tahun ajaran 2019/ 2020.

\section{HASIL PENELITIAN DAN PEMBAHASAN}

Data merupakan sejumlah rangkaian informasi yang sangat diperlukan dalam sebuah penelitian. Deskripsi data dimaksudkan oleh peneliti sebagai gambaran data beserta penjelasannya. Deskripsi data yang akan peneliti sajikan adalah dalam bentuk table dan diagram lingkaran, data yang disajikan meliputi jumlah responden, skor terrendah, skor tertinggi, rata-rata, standar deviasi (SD) dari responden untuk masing-masing variabel, baik variabel bebas $(\mathrm{X})$ maupun variabel terikat $(\mathrm{Y})$.

- Analisis deskriptif statistik

Teknik analisis statistik deskriptif bertujuan untuk menganalisis data dengan menggambarkan data yang sudah dikumpulkan, tanpa membuat kesimpulan yang berlaku umum (generalisasi). Dalam teknik ini, akan diketahui nilai variabel independen dan dependennya, lebih lengkapnya seperti pada table 7 di bawah ini: 
Tabel 7 Hasil olah data melalui SPSS

Descriptive Statistics

\begin{tabular}{|l|r|r|r|r|r|}
\hline & $\mathrm{N}$ & Minimum & Maximum & Mean & Std. Deviation \\
\hline Pengaruh_X & 720 & 55 & 75 & 71.20 & 3.322 \\
PPKn_Y & 720 & 78 & 95 & 86.04 & 2.250 \\
Valid $\bar{N}$ (listwise) & 720 & & & & \\
\hline
\end{tabular}

Sumber: Hasil olah data primer penelitian

Berdasarkan table 7 di atas peneliti bisa menarik kesimpulan bahwa: jumlah total responden sebanyak 720 , skor terrendah $\mathrm{X}$ adalah adalah 55, skor terrendah $\mathrm{Y}$ adalah 75 , skor tertinggi $X$ adalah 75, skor tertinggi $Y$ adalah 95, rata-rata $X$ adalah 71.20, ratarata Y adalah 86.04, standar deviasi X adalah 3.322, dan standar deviasi Y adalah 2.250. Selain dalam bentuk tabel, peneliti juga menyajikan data dalam bentuk diagram lingkaran untuk variabel bebas/ kecerdasan emosional (X), adalah sebagai berikut:

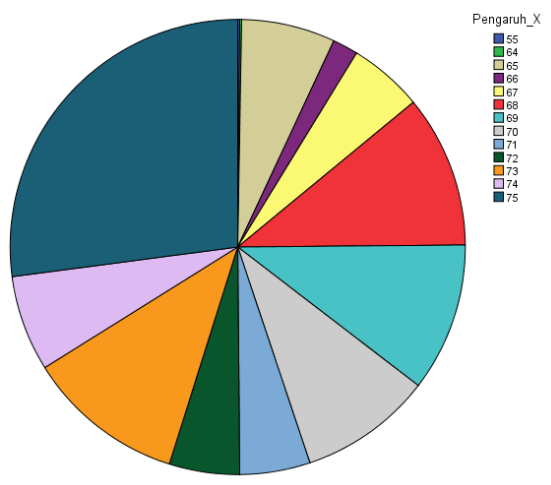

\section{Gambar 2 Diagram lingkaran untuk variabel X (kecerdasan emosional)}

Selanjutnya, peneliti juga menyajikan data dalam bentuk diagram lingkaran untuk variabel terikat/ Prestasi belajar PPKn (Y), adalah sebagai berikut:

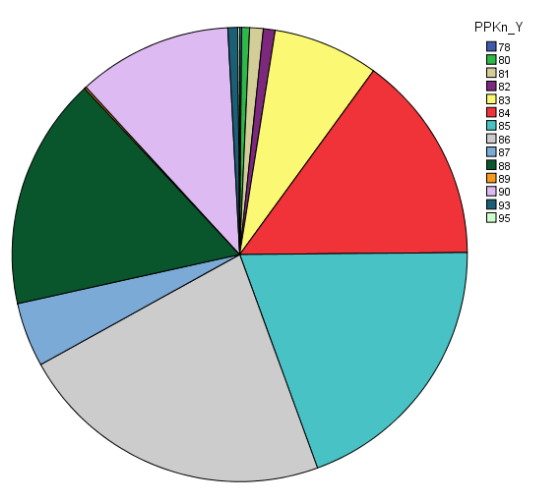

\section{Gambar 3 Diagram lingkaran untuk variabel Y (Prestasi belajar PPKn)}

- Analisis regresi sederhana

Regresi linear sederhana adalah metode statistik yang berfungsi untuk menguji sejauh mana hubungan sebab akibat antara variabel faktor penyebab $(\mathrm{X})$ terhadap variabel akibatnya (Y). Faktor penyebab pada umumnya dilambangkan dengan $\mathrm{X}$ atau disebut 
juga dengan predictor, sedangkan variabel akibat dilambangkan dengan $\mathrm{Y}$ atau disebut juga dengan response. Regresi linear sederhana atau sering disingkat dengan SLR (Simple Linear Regression) dalam hal ini digunakan untuk mengukur pengaruh (signifikansi) dari variabel X (kecerdasan emosional) terhadap variabel Y (Prestasi belajar PPKn).

Pengambilan keputusan dalam uji regresi sederhana dapat mengacu pada dua hal, yakni:

- Membandingkan nilai signifikansi dengan nilai pobabilitas 0,05

- Jika nilai signifikansi $<0,05$, artinya varibael $\mathrm{X}$ berpengaruh terhadap variabel $\mathrm{Y}$.

- Jika nilai signifikansi > 0,05, artinya varibael $\mathrm{X}$ tidak berpengaruh terhadap variabel Y.

- Membandingkan nilat $\mathrm{T}$ hitung dengan $\mathrm{t}$ tabel

- Jika $\mathrm{t}$ hitung $>\mathrm{t}$ tabel, artinya variabel $\mathrm{X}$ berpengaruh terhadap variabel $\mathrm{Y}$.

- Jika t hitung < t tabel, artinya variabel $\mathrm{X}$ tidak berpengaruh terhadap variabel Y.

Pembahasannya, adalah sebagai berikut:

A. Membuat persamaan regresi linier sederhana:

Secara umum rumus persamaan regresi linier sederhana adalah $\mathrm{Y}=\mathrm{a}+\mathrm{bX}$. Sementara untuk mengetahui nlai regresi tersebut kita dapat berpedoman pada output SPSS yang berada pada tabel coefficients berikut ini:

\section{Tabel 8 Hasil olah data melalui SPSS}

Coefficients $^{a}$

\begin{tabular}{|c|c|c|c|c|c|c|}
\hline \multirow{2}{*}{\multicolumn{2}{|c|}{ Model }} & \multicolumn{2}{|c|}{ Unstandardized Coefficients } & $\begin{array}{l}\text { Standardized } \\
\text { Coefficients }\end{array}$ & \multirow[b]{2}{*}{$\mathrm{t}$} & \multirow[b]{2}{*}{ Sig. } \\
\hline & & $\mathrm{B}$ & Std. Error & Beta & & \\
\hline \multirow[t]{2}{*}{1} & (Constant) & 74.298 & 1.748 & & 42.505 & .000 \\
\hline & Pengaruh_X & .165 & .025 & .243 & 6.723 & .000 \\
\hline
\end{tabular}

a. Dependent Variable: PPKn_Y

Sumber: Hasil olah data primer penelitian

\section{Penjelasannya:}

a = angka konstan dari Unstandardized Coefficients, dalam kasus ini nilainya sebesar

74.298. Angak ini merupakan angka konstan yang mempunyai arti bahwa jika tidak ada kecerdasan emosional (X), maka nilai Prestasi belajar PPKn (Y) adalah sebesar 74.298 .

$\mathrm{b}=$ angka koefisien regresi, nilainya sebesar 0,165. Angak ini mempunyai arti bahwa setiap penambahan $1 \%$ kecerdasan emosional (X), maka Prestasi belajar PPKn (Y) akan meningkat sebesar 0,165.

Karena nilai koefisien regresi bernilai positif, maka dengan demikian dapat dikatakan bahwa kecerdasan emosional (X) berpengaruh positif terhadap prestasi belajar PPKn (Y). sehingga persamaan regresinya adalah $\mathrm{Y}=74.298+0,165 \mathrm{X}$ 
B. Uji hipotesis

- Uji Hipotesis dengan membandingkan nilai Signifikansi 0,05

Adapun yang menjadi dasar pengambilan keputusan dalam analisis regresi dengan melihat nilai signifikansi (sig.) hasil output SPSS di atas, adalah:

- $\quad$ H0 = Jika nilai signifikansi $<0,05$ artinya kecerdasan emosional berpengaruh terhadap prestasi belajar PPKn. (H0).

- $\quad \mathrm{Ha}=$ Jika nilai signifikansi > 0,05, artinya kecerdasan emosional tidak ada pengaruh terhadap Prestasi belajar PPKn.

Berdasarkan outpun SPSS di atas, diketahui nilai signifikansi sebesar $0,00<0,05$, sehingga dapat disimpulkan bahwa $\mathrm{H} 0$ ditolak dan Ha diterima, yang mengandung arti bahwa ada pengaruh kecerdasan emosional (X) terhapad prestasi belajar PPKn (Y).

- Uji Hipotesis dengan membandingkan t hitung dengan $t$ tabel

Pengujian hipotesis ini sering disebut juga dengan uji t, dimana dasar pengambilan keputusan dalam uji t adalah, sebagai berikut:

- $\quad \mathrm{H} 0=\mathrm{Jika}$ t hitung $>\mathrm{t}$ tabel, artinya kecerdasan emosional berpengaruh terhadap prestasi belajar PPKn.

- $\quad \mathrm{Ha}=\mathrm{Jika} \mathrm{t}$ hitung $<\mathrm{t}$ tabel, artinya kecerdasan emosional tidak berpengaruh terhadap prestasi belajar PPKn.

Berdasarkan output SPSS di atas, diketahui nilai t hitung sebesar 6,723 dan t tabel sebesar 1,963 atau (t hitung > t table). sehingga dapat disimpulkan bahwa $\mathrm{H} 0$ ditolak dan Ha diterima, yang memiliki arti bahwa ada pengaruh kecerdasan emosional (X) terhadap prestasi belajar PPKn (Y).

- Melihat besarnya pengaruh variabel X terhadap Y

Untuk mengetahui besaranya pengaruh kecerdasan emonional $(\mathrm{X})$ terhadap prestasi belajar PPKn (Y) dalam analisis regresi linier sederhana, dapat berpedoman pada nilai $\mathrm{R}$ Square atau R2 yang terdapat pada outpus SPSS bagian Model Summary, adalah sebagai berikut:

Tabel 9 Hasil olah data melalui SPSS Model Summary

\begin{tabular}{|l|r|r|r|c|}
\hline Model & $\mathrm{R}$ & $\mathrm{R}$ Square & $\begin{array}{c}\text { Adjusted R } \\
\text { Square }\end{array}$ & $\begin{array}{c}\text { Std. Error of the } \\
\text { Estimate }\end{array}$ \\
\hline 1 & $.243^{\mathrm{a}}$ & .059 & .058 & 2.184 \\
\hline
\end{tabular}

Sumber: Hasil olah data primer penelitian

Berdasarkan output SPSS di atas diketahui bahwa nilai R Square sebesar 0,59. Nilai ini mengandung arti bahwa pengaruh kecerdasan emosional $(\mathrm{X})$ terhadap prestasi belajar 
PPKn (Y) adalah sebesar 5,9\% sedangkan 94,1\% prestasi belajar PPKn siswa

dipengaruhi onleh variabel yang lain yang tidak diteliti.

C. Kesimpulan dari uji analisis regresi linear sederhana

Merujuk pada pembahasan di atas, maka dapat peneliti simpulkan bahwa kecerdasan emosional (X) berpengaruh positif terhadap prestasi belakar PPKn (Y) dengan total pengaruh sebesar 5,9\%. Pengaruh positif ini bermakna semakin meningkatnya kecerdasan emosional sesorang siswa maka akan perpengaruh terhadap prestasi belajar PPKn siswa tersebut.

\section{SIMPULAN}

Berdasarkan hasil penelitian dan pembahasan di atas menunjukan bahwa jumlah total responden sebanyak 720, skor terrendah $\mathrm{X}$ adalah adalah 55, skor terrendah $\mathrm{Y}$ adalah 75 , skor tertinggi $\mathrm{X}$ adalah 75 , skor tertinggi $\mathrm{Y}$ adalah 95 , rata-rata $\mathrm{X}$ adalah 71.20 , rata-rata $\mathrm{Y}$ adalah 86.04, standar deviasi $\mathrm{X}$ adalah 3.322, dan standar deviasi $\mathrm{Y}$ adalah 2.250.

Hasil analisis regresi linier sederhana menunjukan bahwa nilai koefisien regresi bernilai positif, maka dengan demikian dapat dikatakan bahwa kecerdasan emosional (X) berpengaruh positif terhadap prestasi belajar PPKn $(\mathrm{Y})$. sehingga persamaan regresinya adalah $\mathrm{Y}=74.298+0,165 \mathrm{X}$.

Maka, dapat peneliti simpulkan bahwa kecerdasan emosional (X) berpengaruh positif terhadap prestasi belakar PPKn (Y) dengan total pengaruh sebesar 5,9\%. Pengaruh positif ini bermakna semakin meningkatnya kecerdasan emosional sesorang siswa maka akan perpengaruh terhadap prestasi belajar PPKn siswa tersebut.

\section{SARAN}

Berdasarkan penelitian, pembahasan dan simpulan yang dihasilkan, agar prestasi belajar mata pelajaran PPKn siswa di SMA Negeri 5 Yoyakarta dapat optimal maka kepada guru, siswa dan sekolah dapatlah diajukan saran-saran sebagai berikut:

1. Bagi Guru

Guru-guru SMA Negeri 5 Yogyakarta dalam melakukan kegiatan belajar mengajar (KBM) mata pelajaran Pendidikan Pancasila dan Kewarganegaraan (PPKn) diharapkan dapat meningkatkan kecerdasan emosional siswa. Supaya para siswa mampu untuk mengelola perasaan, memotivasi diri sendiri dan tegar ketika menghadapi masalah supaya nantinya tidak mengalami frustasi. 
2. Bagi Siawa

Bagi para siswa SMA Negeri 5 Yogyakarta diharapkan dalam mengikuti pembelajaran mata pelajaran PPKn, senantiasa untuk selalu mengedepankan kecerdasan emosional supaya nantinya para siswa SMA Negeri 5 Yogyakarta bisa mendapatkan nilai yang baik, dari hasil yang baik pula.

3. Bagi Sekolah

Dari hasil penelitian ini kepada sekolah di bawah kepemimpinan kepala Sekolah diharapkan dapat meningkatkan kecerdasan emosional siswa untuk menunjang prestasi belajar mata pelajaran PPKn siswanya.

\section{UCAPAN TERIMA KASIH}

Kami mengucapkan terima kasih kepada Direktorat Riset dan Pengabdian kepada Masyarakat, Direktorat Jenderal Pemberdayaan Penelitian dan Pengembangan Kementerian Riset Teknologi dan Pendidikan Tinggi (Direktorat Riset dan Pengabdian Masyarakat, Direktorat Jenderal Penguatan Riset dan Pengembangan Kementerian Riset, Teknologi, dan Pendidikan Tinggi Republik Indonesia) atas dukungan dana untuk penelitian dan publikasi artikel ini dengan nomor Hibah 081 / SP2HMAD / LT / DRPM / 2020.

\section{DAFTAR PUSTAKA}

Agustian Ary Ginanjar. 2005. Rahasia Sukses Membangun Kecerdasan Emosional dan Spiritual. Jakarta: Penerbit Arga.

Anne Abraham. 2006. "The Need for the Integration of Emotional Intelligence Skills in business education", International Journal University of Wollonggong, Wollonggong: Faculty of Commerce, University of Wollonggong.

Arikunto Suharsimi. 2010. Prosedur Penelitian: Suatu Pendekatan Praktek. Jakarta: Rineka Cipta.

Danah Zohar dan Ian Marshall. 2007. Kecerdasan Spiritual. Bandung: Penerbit Mizan.

Djamarah Bahri Saiful. 1994. Prestasi Belajar Dan Kompetensi Guru. Surabaya: Usaha Nasional.

Ellys, J. ed. 2007. Kiat-kiat Meningkatkan Prestasi Belajar Anak. Bandung: Pustaka Hidayah.

Emzir, 2010. Metodologi Penelitian Kualitatif Analisis data. Jakarta: Rajawali Press.

Ghozali Imam. 2005. Aplikasi Analisis Multivariate dengan Program SPSS. Semarang Badan Penerbit Universitas Diponegoro.

Goleman, D. 2005. Kecerdasan Emosi Untuk Mencapai Puncak Prestasi, Jakarta: Penerbit Gramedia. 
Hadi Sutrisno. 1993. Metodoligi Research 2. Yogyakarta: Andi Offset.

Heri Kurnia. 2017. "Pengaruh Kecerdasan Intelektual, Emosional, dan Spiritual Terhadap Prestasi Belajar Pendidikan Kewarganegaraan Siswa SMA Negeri seKota Yogyakarta Tahun Ajaran 2016/2017”, Tesis: Fakultas Pascasarjana, Program Studi Pendidikan Ilmu Pengetahuan Sosial, Universitas PGRI Yogyakarta.

Iqbal Hasan. 2010. Analisis Data Penelitian dengan Statistik. Jakarta: PT Bumi Angkasa.

Oemar Hamalik. 2012. Proses Belajar Mengajar. Jakarta: Bumi Angkasa.

Slameto. 2010. Belajar dan Faktor-faktor yang Mempengaruhinya. Jakarta: Rineka Cipta.

Sudjiono Anas. 1986. Teknik Evaluasi Pendidikan Suatu Pengantar. Yogyakarta: U. D. Rama.

Sugiyono. 2005. Metode Penelitian Administrasi. Bandung: Penerbit Alfabeta.

Sugiono. 2010. Metodologi Penelitian Pendidikan: Pendekatan Kuantitatif, Kualitatif, dan R \& D. Bandung: Alfabeta.

Sugiono. 2011. Metodologi Penelitian Kuantitatif, Kualitatif dan R \& D. Bandung: Alfabeta.

Sugiono. 2012. Statistik untuk Penelitian. Bandung: Alfabeta.

Sugiyono. 2014. Metode Penelitian Manajemen. Bandung: Penerbit Alfabeta.

Syah Muhibbin. 2004. Psikologi Pendidikan dengan Pendekatan Baru. Bandung: PT Remaja Rosda Karya.

Syaiful Bahri Djamarah. 2011. Psikologi Belajar. Jakarta: Rineka Cipta.

Undang-undang Republik Indonesia Nomor 20 Tahun 2003. 2010. Sistem Pendidikan Nasional. Bandung: Citra Umbara.

Djasuli M. dan Hidayah Nur. 2013. "Pengaruh Kecerdasan Intelektual, Emosional, dan Spiritual Terhadap Kinerja Variabel Moderasi Kompetensi di Kabupaten Lamongan", Studi Kasus di SKPD Kabupaten Lamongan, Universitas Trunojoyo Madura.

Hakim Andi. 2013. "Pengaruh Kecerdasan Intelektual, Kecerdasan Emosional, dan kecerdasan Spiritual Terhadap Prestasi Belajar Siswa SMA Negeri di Surakarta Tahun Pelajaran 2012/ 2013”, Tesis: Fakultas Pascasarjana, Program Studi Pendidikan Ekonomi, Universitas Sebelas Maret Surakarta.

Nachiappan, dkk. 2013. "Analysis of Cognition Integration in Intelligence Quotient (IQ), Emotional Quotient (EQ) and Spiritual Quotient (SQ) in Transforming Cameron Highlands Youths through Hermeneutics Pedagogy". Disampaikan dalam Konferensi Internasional tentang Pendidikan \& Psikologi Pendidikan 2013 (ICEEPSY 2013), Sultan Idris Education University, Tanjung Malim, 35900, Malaysia.

Rahmasari Lisda. 2012. "Pengaruh Kecerdasan Intelektual, Kecerdasan Emosional dan Kecerdasan Spiritual Terhadap Kinerja Karyawan”, Jurnal Fakultas Ekonomi Universitas AKI, Semarang. 
Saifudin Azwar. 2010. Pengantar Psikologi Inteligensi. Yogyakarta: Pustaka Pelajar.

Surahmad, Winarto. 1992. Pengantar Penelitian Ilmiah Dasar Metode dan Teknik. Bandung: Tarsito.

Tikollah, dkk 2006. "Pengaruh Kecerdasan Intelektual, Kecerdasan Emosional, dan Kecerdasan Spiritual Terhadap Sikap Etis Mahasiswa Akuntansi (Studi Pada Perguruan Tinggi Negeri Di Kota Makassar Provinsi Sulawesi Selatan)". Padang: Simposium Nasional Akuntansi 9 Jurnal multiparadigma lecture, Universitas Brawijaya.

Trihandini, 2005. “Analisis Pengaruh Kecerdasan Intelektual, Kecerdasan Emosi, dan Kecerdasan Spiritual Terhadap Kinerja Karyawan”, Tesis: Fakultas Pascasarjana, Program Studi Magister Manajemen, Universitas Diponegoro, Semarang.

Kurniawan Aris. 06 Nopember 2015. "12 Pengertian Belajar menurut Para Ahli Pendidikan". Guru Pendidikan (online). http://www.gurupendidikan.com/101pengertian- belajar-menurut- para-ahli-pendidikan.

Solihin Akhmad. 12 Juli 2015. "Kumpulan Definisi Dan Pengertian Belajar Menurut Para Ahli". VISIUNIVERSAL Blog Tentang Ilmu Pengetahuan dan Teknologi Terbaru. $\quad$ http://visiuniversal.blogspot.co.id/2015/07/kumpulan-definisidanpengertian.html,

Data pokok pendidikan dasar dan menengah: http://dapo.dikdasmen.kemdikbud.go.id/sekolah/D6F25C380802766BBE8D

Kurnia, H. (2014). PENGARUH KEAKTIFAN BERORGANISASI TERHADAP INDEKS PRESTASI KUMULATIF MAHASISWA UNIVERSITASCOKROAMINOTO YOGYAKARTA. Academy of Education Journal, 5(2). https://doi.org/10.47200/aoej.v5i2.120

Kurnia, H. (2016). SIKAP NASIONALISME MAHASISWA UNIVERSITAS COKROAMINOTO YOGYAKARTA TAHUN AKADEMIK 2015-2016. Academy of Education Journal, 7(2), 79-88. https://doi.org/10.47200/aoej.v7i2.405

Kurnia, H. (2019). PENGARUH KECERDASAN INTELEKTUAL, EMOSIONAL DAN SPIRITUAL TERHADAP PRESTASI BELAJAR PENDIDIKAN KEWARGANEGARAAN. Academy of Education Journal, 10(01), 1-21. https://doi.org/10.47200/aoej.v10i01.267

Kurnia, H., \& Septera, G. (2019). Penerapan Model Pembelajaran Kooperatif Tipe Make A Match Untuk Meningkatkan Hasil Belajar. Academy of Education Journal, 10(02), 109-121. https://doi.org/10.47200/aoej.v10i02.277

Kurnia, H., \& Widayanti, F. (2020). PENGARUH PENDIDIKAN KARAKTER KEPANDUAN HIZBUL WATHON TERHADAP PRESTASI BELAJAR SISWA DI SMP MUHAMMADIYAH 7 YOGYAKARTA. Academy of Education Journal, 11(01), 75-86. https://doi.org/10.47200/aoej.v11i01.318. 